\title{
Kepastian Hukum Putusan Mahkamah Agung RI No. 129 K/TUN/2011 dan Putusan Mahkamah Agung RI No. 225 K/TUN/2014 Terhadap Izin Kuasa Pertambangan di Kabupaten Konawe Utara
}

\author{
Legal Certainty of the Decision of the Supreme Court of the Republic of \\ Indonesia No. 129 K/TUN/2011 and Decision of the Supreme Court of the \\ Republic of Indonesia No. 225 K/TUN/2014 towards Mining Permit in \\ Konawe Utara District
}

\author{
Abdul Razak \\ Perhimpunan Advokat Seluruh Indonesia \\ E-mail: harnabagw@gmail.com \\ Muhammad Jufri Dewa \\ Pascasarjana Universitas Halu Oleo \\ E-mail: muh.jufridewa@yahoo.com \\ Kamaruddin Jafar \\ Pascasarjana Universitas Halu Oleo \\ E-mail: Kamaruddinjafar88@gmail.com
}

\begin{abstract}
Mining License has become a legal formal in order to implement activities for natural productions which are contained from the natural resources. This activity aimed for people prosperity as mentioned in the Constitution 1945 which is also supervised by the State-Owned Enterprises or Local-owned as well as Private-Owned. Based on explanation above, it is revealed that how is the legal certainty on Supreme Court Decree which is contradictive onto Mining Mandate License toward the same mining area and what is a legal consequence which is caused by illegal certainty on Supreme Court Decree onto the same of mining area.

This study used a normative research which is consisted of case approach, statute approach, and conceptual approach.

Based on affirmation above, it is here asserted that the Decree of Supreme Court of 225 K/TUN/2014 is as the cause of overlap for Mining Area due to Judex Factie for Administrative Court. And the consequence of overlap decree is the illegal certainty that causing as follow: (1) the absence of mining activates by the holder of Mining License for P.T Aneka Tambang Co. as well as the 11 Companies that overlapped with
\end{abstract}


Mining License Area; (2) Happened to the huge of termination of employment; (3) the Income State become lose due to overlapped mining license.

Keyword: Legal Certainty of Decree; Mining Area; Mining License

Abstrak: Izin Usaha Pertambangan merupakan legalitas untuk melaksanakan kegiatan pengelolaan hasil-hasil alam yang terkandung dalam perut bumi dengan tujuan untuk menciptakan kemakmuran rakyat, sebagaimana yang diamanahkan UUD Negara Republik Indonesia tahun 1945 kegiatan usaha dibidang pertambangan dapat dikelola langsung oleh negara melalui Badan Usaha Milik Negara dan atau badan usaha milik daerah dan/atau badan usaha milik swasta dan atau perorangan dan koperasi.

Berdasarkan uraian di atas, ditemukan masalah antara lain, bagaimana Kepastian Hukum terhadap Putusan Mahkamah Agung Republik Indonesia yang Berbeda atas Izin Kuasa Pertambangan pada wilayah pertambangan yang sama dan Apa konsekuensi hukum yang timbul akibat ketidakpastian hukum atas putusan mahkamah agung pada lokasi pertambangan yang sama.

Adapun Metode Penelitian yang digunakan adalah normatif, dengan Pendekatan kasus (case approach), pendekatan peraturan perundang-undangan (statute approach), dan pendekatan konseptual (conseptual approach).

Berdasarkan uraian di atas maka dapat disimpulkan antara lain, Putusan Mahkamah Agung Republik Indonesia Nomor 225 K/TUN/2014 sebagai penyebab tumpang tindih WIUP karena judex facti pada Pengadilan Tata Usaha Negara. Dan akibat tumpang tindih putusan berkonsekuensi tidak adanya kepastian hukum, yang mengakibatkan: (1) Tidak adanya Kegiatan Penambangan oleh Pemegang Hak Izin Pertambangan baik PT. Aneka Tambang Maupun 11 Perusahaan yang tertindih WIUP-nya (2) terjadi Pemutusan hubungan Kerja besar besaran dan (3) Penghasilan Daerah dan Negara menjadi hilang dari sektor Pertambangan di WIUP yang tumpang tindih.

Kata kunci: Kepastian Hukum Putusan; Wilayah Pertambangan; Izin Kuasa Pertambangan

\section{PENDAHULUAN}

Izin Usaha Pertambangan merupakan legalitas untuk melaksanakan kegiatan pengelolaan hasil-hasil alam yang terkandung dalam perut bumi dengan tujuan untuk menciptakan kemakmuran rakyat, sebagaimana yang diamanahkan UUD Negara Republik Indonesia tahun 1945 kegiatan usaha dibidang pertambangan dapat dikelola langsung oleh negara melalui Badan Usaha Milik Negara dan atau badan usaha milik daerah dan atau badan usaha milik swasta dan atau perorangan dan koperasi.

Kewenangan Pemberian Izin Usaha Pertambangan menurut Undang-Undang No. 4 tahun 2009,ada pada Bupati/Walikota, Gubernur dan Menteri. Ketiga pejabat Negara tersebut dalam menerapkan kewenangannya dibatasi dengan wilayah kerja masingmasing. Wilayah kerja Bupati/Wali Kota berada pada Wilayah Kabupaten atau Kota, demikian pula dengan Gubernur wilayah kerjanya ada pada lintas Kabupaten/Kota Sedangkan Menteri ada pada wilayah lintas Provinsi. 
Setelah berlakunya Undang-Undang No. 23 tahun 2014 tentang Pemerintahan Daerah, Kewenangan Pemerintah Kabupaten/Kota dibidang Pertambangan menjadi hilang, kewenangan tersebut sepenuhnya diambil alih Pemerintah Provinsi dan Pemerintah Pusat dalam hal ini Gubernur dan Menteri. Sengketa hak Kuasa Pertambangan menyertai pengelolaan sumber daya alam, baik antara pemerintah dengan Pemegang hak Kuasa Pertambangan, begitu pula antara pemegang hak kuasa Pertambangan itu sendiri yang berkepanjangan sehingga menimbulkan ketidakpastian hukum dalam pemanfaatan dan pengelolaannya.

Sengketa Kuasa Pertambangan di Kabupaten Konawe Utara terjadi dalam dua kategori, pertama, sengketa akibat keluarnya Keputusan Pejabat Tata Usaha Negara dengan pemegang hak Kuasa Pertambangan, dan kedua, antara pemegang hak Kuasa Pertambangan itu sendiri, akibat dikeluarkannya Keputusan Tata Usaha Negara menyangkut izin kuasa Pertambangan oleh Bupati telah berproses hingga ke Mahkamah Agung dalam objek sengketa yang berbeda namun wilayah pertambangannya sama dan telah mengalami dua proses hukum yang terpisah.

Berdasarkan Uraian di atas, maka rumusan masalah dalam penelitian ini antara lain: (1) Bagaimanakah Kepastian Hukum terhadap Putusan Mahkamah Agung Republik Indonesia yang Berbeda atas Izin Kuasa Pertambangan pada wilayah pertambangan yang sama dalam kasus Putusan Mahkamah Agung Republik Indonesia Nomor. 129 K/TUN/2011 dan Putusan MARI No. 225 K/TUN/2014? (2) Apa konsekuensi hukum yang timbul akibat ketidakpastian hukum wilayah pertambangan yang sama lokasinya?

\section{METODE PENELITIAN}

Tipe yang digunakan dalam penelitian ini adalah normatif, dimana tipe penelitian normatif ini adalah tipe penelitian hukum yang meletakkan hukum sebagai sebuah bangunan sistem norma. ${ }^{1}$ Tipe penelitian normatif ini dilakukan dengan Cara mengkaji berbagai peraturan hukum yang bersifat formal seperti Undang-Undang Dasar Negara Republik Indonesia Tahun 1945, Undang-undang Republik Indonesia Nomor 23 Tahun 2014 tentang Pemerintahan Daerah, Undang-Undang Republik Indonesia Nomor 4 tahun 2009 tentang Pertambangan Mineral dan Batubara dan konsep teoritis yang kemudian dihubungkan dengan permasalahan yang menjadi obyek dalam pembahasan penelitian

1 Mukti Fajar dan Yulianto Achmad, Dualisme Penelitian Hukum Normatif dan Empiris, Yogyakarta: Pustaka Pelajar, 2010, hlm. 33. 
nanti. Penelitian ini lebih menekankan pada Tumpang tindih Wilayah Pertambangan berdasarkan Undang-Undang Republik Indonesia Nomor 4 tahun 2009 tentang Pertambangan Mineral dan Batubara yang masih kabur, sehingga dibutuhkan penafsiran historis terhadap prinsip hukum terhadap sejarah lahirnya mekanisme Izin Usaha Pertambangan yang berasal dari Penyesuaian Kuasa Pertambangan menjadi Izin Usaha Pertambangan dalam Undang-Undang Republik Indonesia Nomor 4 tahun 2009 tentang Pertambangan Mineral dan Batubara hingga turunan Peraturan dalam Peraturan Menteri Energi dan Sumber daya Mineral. Pendekatan yang selanjutnya Akan digunakan dalam pembahasan tesis ini yaitu: Pendekatan kasus (case approach) dilakukan dengan cara melakukan telaah terhadap kasus-kasus yang berkaitan dengan isu yang dihadapi yang telah menjadi putusan pengadilan yang telah mempunyai kekuatan hukum yang tetap; Pendekatan peraturan perundang-undangan (statute approach) yaitu dengan menelusuri setiap peraturan perundang-undangan yang mengatur mekanisme izin pertambangan; Pendekatan konseptual (conseptual approach) yaitu gabungan Antara asas hukum dan doktrin para ahli hukum ketatanegaraan dalam memformulasikan mekanisme pemberian izin dan pencabutan usaha tambang. ${ }^{2}$

\section{ANALISIS DAN PEMBAHASAN}

Kepastian Hukum Terhadap Putusan Mahkamah Agung Republik Indonesia Yang Berbeda Atas Izin Kuasa Pertambangan pada Wilayah Pertambangan Yang Sama Dalam Kasus Putusan Mahkamah Agung Republik Indonesia Nomor. 129 K/TUN/2011 Dan Putusan MARI NO. 225 K/TUN/2014

Kesepakatan dalam Rapat Koordinasi terlihat jelas adanya Mal Administrasinya karena menyebabkan hilangnya Kepastian hukum terhadap Hak Izin Pertambangan dan pembangkangan terhadap Putusan yang telah berkekuatan hukum tetap serta menimbulkan kerugian bagi pihak perusahaan lain Pemegang Hak Izin Pertambangan karena tumpang tindih wilayah Pertambangan pada WIUP Lasolo, Lalindu dan Mandiodo, sehingga tidak dapat dilakukan kegiatan penambangan dalam wilayah tersebut. hal ini dapat dilihat dari urutan tanggal penerbitan Surat Keputusan Penjabat Bupati Konawe Utara serta objek surat Keputusan itu sendiri yakni sebagai berikut:

2 Peter Mahmud Marzuki, Penelitian Hukum, Jakarta: Kencana Prenada Media Group, 2011, hlm. 93. 
1) Tanggal 11 Januari 2010 diterbitkan antara lain: a) SK Bupati Konawe Utara Nomor 04 tahun 2010 tanggal 11 Januari 2011 tentang Pembatalan Surat Keputusan Bupati Konawe Utara Nomor 153 tahun 2008 tanggal 17 Maret 2008 tentang Revisi Batas dan Luas Kuasa Pertambangan Eksploitasi (Kw 99 STP057 A/Sultra) (Objek sengketa Putusan Pengadilan Tata Usaha Negara Kendari No. 10/G/2008/PTUN-Kdi) ; b) SK Bupati Konawe Utara Nomor 05 Tahun 2010 tanggal 11 Januari 2011 tentang Pembatalan Perizinan Kuasa Pertambangan yang diterbitkan oleh Pejabat Bupati Konawe Utara dalam wilayah Kuasa Pertambangan PT. Aneka Tambang (Persero), Tbk di Kabupaten Konawe Utara; dan c) SK Bupati Konawe Utara Nomor 06 Tahun 2010 tanggal 11 Januari 2011 tentang Pembatalan Surat Keputusan Bupati Konawe Utara No. 267 tahun 2007 tanggal 29 September 2007 terhadap Pemberian Kuasa Pertambangan Eksplorasi (KW 07 STP 034) Kepada PT. Duta Inti Perkasa Mineral. d) SK Penjabat Bupati Konawe Utara No. 14 tahun 2010 tanggal 11 Januari 2010 tentang Pemberian Izin Usaha Pertambangan Eksplorasi kepada PT. Aneka Tambang (KW 99 STP 057b) seluas 7.371 Ha. e) SK Penjabat Bupati Konawe Utara No. 12 tahun 2010 tanggal 11 Januari 2010 tentang Pemberian Izin Usaha Pertambangan Eksplorasi kepada PT. Aneka Tambang (KW 99 NPP 024) seluas 6. 376 Ha. f) SK Penjabat Bupati Konawe Utara No. 13 tahun 2010 tanggal 11 Januari 2010 tentang Pemberian Izin Usaha Pertambangan Operasi Produksi kepada PT. Aneka Tambang (KW 99 NPP 001) seluas 3.047 Ha.

2) Tanggal 8 Februari 2010 dilakukan Penggabungan Izin Usaha Pertambangan Eksplorasi SK No. 14 tahun 2010 dengan SK No. 12 tahun 2010 menjadi Surat Keputusan Penjabat Bupati Konawe Utara No. 63 tahun 2010 tentang Pemberian Izin Usaha Pertambangan Eksplorasi kepada PT. Aneka Tambang (KW10 PEB ER 001) seluas 13410 Ha.

3) Tanggal 29 Maret 2010 dilakukan Peningkatan Surat Keputusan Penjabat Bupati Konawe Utara No. 63 Tahun 2010 tentang Pemberian Izin Usaha Pertambangan Eksplorasi kepada PT. Aneka Tambang ditingkatkan ke Izin Usaha Pertambangan Operasi Produksi dengan surat Keputusan Penjabat Bupati Konawe Utara Nomor. 105 Tahun 2010 tentang Pemberian Peningkatan Izin Usaha Pertambangan Eksplorasi menjadi Izin Usaha Pertambangan Operasi Produksi PT. Aneka Tambang (10 MRT OP 001) seluas $13.410 \mathrm{Ha}$ 
4) Tanggal 29 April 2010 dilakukan Penggabungan Izin Usaha Pertambangan Operasi Produksi SK No. 105 tahun 2010 (pada poin 3) dengan SK No. 13 tahun 2010 menjadi Surat Keputusan Penjabat Bupati Konawe Utara No. 158 tahun 2010 tentang Pemberian Izin Usaha Pertambangan Operasi Produksi PT. Aneka Tambang (KW10 APR OP 005) seluas $16.920 \mathrm{Ha}$.

Berdasarkan urutan tanggal penerbitan Surat Keputusan Penjabat Bupati Konawe Utara terkait WIUP Lasolo, Lalindu, Mandiodo akan terlihat Keputusan Pejabat Tata Usaha Negara yang tidak berdasarkan peraturan perundang-undangan yang berlaku sehingga mengarah pada tindakan Mal Administrasi yang berpotensi pada kejahatan Korporat sebagaimana terurai pada poin 1,2,3 dan 4 tersebut di atas dapat di analisa lebih lanjut sebagai berikut:

Rangkaian Pembatalan perizinan, dan penerbitan IUP Eksplorasi maupun IUP OP baru serta penggabungan Izin Usaha Pertambangan membawa akibat Tumpang tindihnya WIUP pada WIUP Lasolo, Lalindu dan Mandiodo. Berakibat hilangnya kepastian Hukum atas wilayah Pertambangan dalam WIUP tersebut dan menimbulkan kerugian pada pihak perusahaan lain hal ini terjadi karena pada saat Pembatalan Perizinan Kuasa Pertambangan yang diterbitkan oleh Pejabat Bupati Konawe Utara dalam wilayah Kuasa Pertambangan PT. Aneka Tambang (Persero), Tbk di Kabupaten Konawe Utara. sebagaimana termuat dalam Surat Keputusan Penjabat Bupati Konawe Utara No. 5 tahun 2010. Pada poin Memutuskan diktum Pertama disebutkan membatalkan seluruh Kuasa Pertambangan yang bertumpang tindih dengan wilayah kuasa Pertambangan PT. Aneka Tambang di Kabupaten Konawe Utara. kemudian ditindak lanjuti dengan menerbitkan beberapa SK Penjabat Bupati Konawe Utara dalam bentuk IUP yaitu IUP Eksplorasi dan IUP Operasi Produksi kepada PT. Aneka Tambang sebagaimana poin 1 tersebut di atas. Sehingga terjadi Tumpang Tindih WIUP antara PT. Aneka Tambang dengan WIUP pihak lain sehingga tidak jelas lagi WIUP mana yang terlegitimasi melakukan kegiatan Penambangan karena masing-masing pihak merasa berhak atas WIUP yang dimilikinya hal demikian menimbulkan ketidakpastian hukum dan kerugian pada pihak lain yang ditindih WIUP-nya.

Dua WIUP digabung menjadi satu WIUP yaitu WIUP SK Penjabat Bupati Konawe Utara No. 14 tahun 2010 tanggal 11 Januari 2010 tentang Pemberian Izin Usaha Pertambangan Eksplorasi kepada PT. Aneka Tambang (KW 99 STP 057b) seluas 7.371 Ha. digabung dengan WIUP SK Penjabat Bupati Konawe Utara No. 12 tahun 2010 tanggal 11 
Januari 2010 tentang Pemberian Izin Usaha Pertambangan Eksplorasi kepada PT. Aneka Tambang (KW 99 NPP 024) seluas 6. 376 Ha. Menjadi IUP Eksplorasi SK Bupati Konawe Utara No. 63 tahun 2010 Tanggal 8 Februari 2010 tentang Pemberian Izin Usaha Pertambangan Eksplorasi kepada PT. Aneka Tambang (KW10 PEB ER 001) seluas 13410 Ha. kemudian tanggal 29 Maret 2010 ditingkatkan menjadi IUP Operasi Produksi dengan Surat Keputusan Penjabat Bupati Konawe Utara No. 105 Tahun 2010 tentang Pemberian Peningkatan Izin Usaha Pertambangan Eksplorasi menjadi Izin Usaha Pertambangan Operasi Produksi PT. Aneka Tambang (10 MRT OP 001) seluas 13.410 Ha. dalam rentang waktu hanya 21 hari saja sejak pemberian IUP Eksplorasi telah ditingkatkan menjadi IUP Operasi Produksi sedangkan Pasal 39 ayat (1) huruf n UU RI. No. 4 tahun 2009 tentang Pertambangan Mineral dan Batubara disebutkan:

"IUP Eksplorasi sebagaimana dimaksud dalam Pasal 36 ayat (1) huruf a wajib memuat ketentuan sekurang-kurangnya: huruf n (Amdal)"3

Pasal 1 angka 25 UU RI. No. 4 tahun 2009 tentang Pertambangan Mineral dan Batubara menyebutkan:

“Analisa Mengenai Dampak Lingkungan, yang selanjutnya disebut amdal, adalah Kajian mengenai dampak besar dan penting suatu usaha dan/atau kegiatan yang direncanakan pada lingkungan hidup yang diperlukan bagi proses pengambilan keputusan tentang penyelenggaraan usaha dan/atau kegiatan" 4 .

Dengan demikian amdal dan/atau adanya data kajian study kelayakan merupakan salah satu syarat yang wajib dipenuhi Izin Usaha Pertambangan Eksplorasi untuk dapat ditingkatkan Menjadi Izin Usaha Pertambangan Operasi Produksi. Jadi sangat tidak logis amdal dan/atau data Kajian study kelayakan telah diperoleh PT. Aneka tambang hanya dalam waktu 21 hari untuk WIUP IUP Eksplorasi SK Bupati Konawe Utara No. 63 tahun 2010 tentang Pemberian Izin Usaha Pertambangan Eksplorasi. PT. Aneka Tambang sehingga WIUP IUP Eksplorasi OP artinya Izin Usaha Pertambangan Eksplorasi SK No. 63 tahun 2010 belum dan/atau tidak memiliki amdal dan/atau data kajian study kelayakan tetap ditingkatkan menjadi Izin Usaha Pertambangan Operasi Produksi dengan SK IUP Operasi Produksi No. 105 tahun 2010 tentang Pemberian Peningkatan Izin Usaha Pertambangan Eksplorasi menjadi Izin Usaha Pertambangan Operasi Produksi PT. Aneka Tambang (10 MRT OP 001) seluas 13.410 Ha. dengan demikian proses Peningkatan SK IUP 
Eksplorasi PT. Aneka Tambang No. 63 tahun 2010 menjadi IUP Operasi Produksi SK No. 105 tahun 2010 cacat hukum. Maka dengan sendirinya Penggabungan IUP Operasi Produksi SK 105 tahun 2010 dengan IUP Operasi Produksi SK No. 13 tahun 2010 tentang pemberian Izin Usaha Pertambangan Operasi Produksi PT. Aneka Tambang. Menjadi IUP Operasi Produksi SK Bupati Konawe Utara No. 158 tahun 2010 Tanggal 29 April 2010 tentang Pemberian Izin Usaha Pertambangan Operasi Produksi PT. Aneka Tambang (KW10 APR OP 005) seluas 16.920 Ha. cacat hukum juga. Penggabungan IUP Operasi Produksi SK 105 tahun 2010 dengan IUP Operasi Produksi SK No. 13 tahun 2010 tentang pemberian Izin Usaha Pertambangan Operasi Produksi PT. Aneka Tambang. Menjadi IUP Operasi Produksi SK Bupati Konawe Utara No. 158 tahun 2010 Tanggal 29 April 2010 tentang Pemberian Izin Usaha Pertambangan Operasi Produksi PT. Aneka Tambang (KW10 APR OP 005) seluas 16.920 Ha. merupakan tahap akhir dari penggabungan seluruh WIUP PT Aneka Tambang di WIUP Lasolo, Lalindu dan Mandiodo. Kabupaten Konawe Utara.

\section{Konsekuensi Hukum Yang Timbul Akibat Ketidakpastian Hukum Wilayah Pertambangan Yang Sama Lokasinya}

Monopoli wilayah Pertambangan oleh satu Perusahaan dapat dikategorikan telah memonopoli wilayah pertambangan apabila sekurangnya sepertiga izin wilayah pertambangan dikuasai dan/atau dipegang oleh satu perusahaan apakah itu BUMN, Perusahaan Swasta Nasional, Perseorangan ataupun Koperasi tidak boleh terjadi karena dapat menimbulkan ketidakadilan. Keadilan merupakan salah satu asas dalam UndangUndang Republik Indonesia Nomor 4 tahun 2009 tentang Pertambangan Mineral dan Batubara sehingga apabila dalam wilayah pertambangan tertentu terdapat satu perusahaan yang monopoli wilayah pertambangan maka dapat dikaitkan asas keadilan dalam UU tersebut tidak dilaksanakan sebagaimana mestinya. ${ }^{5}$

Keadilan Menurut Kamus Besar Bahasa Indonesia adalah tidak berat sebelah; tidak memihak; atau berpihak atau berpegang pada yang benar; sepatutnya; tidak sewenangwenang. Keadilan berhubungan dengan Kondisi tertentu berkaitan dengan prinsip keadilan menurut John Rawls dalam teorinya yang disebut keadilan Prosedur Murni

5 Lihat Pasal 2 Undang-undang Republik Indonesia No. 4 Tahun 2009 tentang Pertambangan Mineral dan Batubara 
menyebutkan bahwa ${ }^{6}$ prosedur atau cara untuk menuju hasil yang adil haruslah benarbenar dijalankan sebab tidak ada kriteria independen yang bisa dijadikan acuan agar hasil yang nyata bisa adil kondisi tertentu adalah adil menyatakan bahwa Kondisi tertentu telah adil. Lebih lanjut John Rawls juga menyatakan bahwa kondisi tertentu adalah adil karena bisa dicapai dengan mengikuti prosedur yang fair. Berangkat dari pandangan teori John Rawls tersebut Pemberian Perizinan PT. Aneka Tambang tidak didasarkan atas prosedur yang fair karena Perpanjangan Perizinan KP No. 215 tahun 2004 perpanjangan pertama dari SK KP Eksplorasi No. 400/2001 kemudian diberi perpanjangan kedua dengan KP Eksplorasi No. 162 tahun 2005 (KW 99 STP 057b) pada diktum pertama dalam SK disebutkan: memberikan Perpanjangan Kedua KP Eksplorasi untuk jangka waktu 1(satu) tahun berturut-turut. Dari perpanjangan tersebut berarti SK KP Eksplorasi No. 162 tahun 2005 berakhir masa berlakunya pada tahun 2006. Pasal 9 ayat (3) Peraturan Pemerintah No. 75 tahun 2001 tentang Perubahan kedua atas Peraturan Pemerintah nomor 32 tahun 1969 tentang Pelaksanaan Undang-undang Nomor 11 tahun 1967 tentang Ketentuan-ketentuan Pokok Pertambangan menyebutkan: "Menteri, Gubernur, Bupati/Walikota sesuai kewenangannya dapat memperpanjang jangka waktu sebagaimana dimaksud dalam ayat (2) sebanyak 2 (dua) kali, setiap kalinya untuk jangka waktu 1 (satu) tahun". Pada tahun 2007 SK KP. Eksplorasi No. 162 tahun 2005 diperpanjang lagi dengan perpanjangan ke tiga SK. KP Eksplorasi No. 228 tahun 2007. SK KP Eksplorasi No. 162 telah berakhir masa berlakunya tahun 2006 tetap diperpanjang untuk ketiga kalinya ditahun 2007 dengan SK KP Eksplorasi 228 tahun 200 pada dictum Pertama disebutkan memberikan perpanjangan Kuasa Pertambangan untuk jangka waktu 3 (tiga) tahun berturut-turut kemudian disesuaikan menjadi IUP Eksplorasi No. 14 tahun 2010. Terkait penyesuaian dan penggabungannya telah dijelaskan pada bagan penyesuaian dari KP menjadi IUP dalam pembahasan terdahulu. Sengaja dikemukakan kembali terkait dengan Teori Keadilan dalam pembahasan Bab ini John Rawls ${ }^{7}$ menyatakan bahwa kondisi tertentu adalah adil karena bisa dicapai dengan mengikuti prosedur yang fair Pasal 9 PP 75/2001 tersebut, tidak mengenal adanya perpanjangan ketiga dan diperpanjang sebelum masa berlakunya berakhir dan setiap perpanjangan hanya untuk 1 (satu) tahun.

6 Erwantoni Yakoeb, Kewenangan Hakim Menetapkan Tersangka, Bandung: Logoz Publishing, 2017, hlm 63.

7 Ibid. 
Penyesuaian SK KP Eksplorasi No.228 tahun 2007 yang kemudian disesuaikan menjadi IUP Eksplorasi merupakan cikal bakal terbitnya SK IUP OP No. 158 tahun 2010. Karena SK IUP OP No. 158 merupakan penggabungan dari beberapa IUP Eksplorasi No. 12 tahun 2010, IUP Eksplorasi NO. 14 tahun 210, IUP Eksplorasi no. 63 Tahun 2010, IUP OP No. 105 tahun 2010 dan IUP OP No. 13 tahun 2010 proses Penggabungan ini cacat hukum karena menyalahi ketentuan Pasal 9 tersebut maka dengan sendiri SK IUP OP No. 158 tahun 2010 cacat hukum juga. Dan/atau IUP OP SK Bupati Konawe Utara NO. 158 tahun 2010 merupakan satu kesatuan yang tidak terpisahkan dengan IUP-IUP Lain dalam 3 WIUP Lasolo, Lalindu dan Mandiodo termasuk luas maupun Perpanjangan KP-KP tersebut merupakan bagi yang tidak terpisahkan dengan IUP OP SK Bupati Konawe Utara No. 158 tahun 2010.

Keadilan dapat dicapai apabila Monopoli wilayah Pertambangan yang disengketakan ditiadakan seperti yang telah dilakukan Penjabat Bupati Drs. H. Aswad Sulaiman P M.Si. dengan Penataan serta menerbitkan Surat Penyesuaian Wilayah Pertambangan berdasarkan UU No. 11 tahun 1967 yang berlaku Positif saat itu. Bila Penjabat setelah Drs. H. Aswad Sulaiman melanjutkan dan memperkuat Penyesuaian yang dilakukan Drs. H. Aswad Sulaiman dan berpedoman pada hal tersebut yakni penyesuaian wilayah pertambangan, maka dengan sendirinya tidak ada sengketa wilayah Pertambangan antara Pemerintah, dengan Pengusaha Pertambangan dan/atau antara Pengusaha dengan Pengusaha Pertambangan sendiri sengketa tumpang tindih Wilayah Pertambangan tidak akan berkepanjangan dan akan tercipta kepastian hukum sehingga tidak sejengkal pun wilayah pertambangan tidak dapat di olah dan semua WIUP dapat dimanfaatkan.

Kepastian Hukum dan Keadilan dalam WIUP yang tumpang tindih sangat diharapkan oleh para Pengusaha Pertambangan agar perizinan mereka dapat berdaya guna demi kepentingan pengusaha sendiri, Masyarakat sekitar tambang, Daerah dimana Lokasi tersebut berada dan tentunya bagi kepentingan Nasional. Untuk menciptakan hal tersebut diharapkan peran aktif Pemerintah Daerah. Justru yang terjadi saat ini sengketa tumpang tindih WIUP semakin berlarut larut membawa konsekuensi tidak satu pun Perusahaan Pertambangan yang memegang Izin Usaha Pertambangan dapat melakukan kegiatan pertambangan berdasarkan Izin yang dipegangnya tentunya berakibat tidak terserapnya tenaga kerja dan hilangnya Penghasilan Daerah dan Negara dari sektor Pertambangan. Pemegang kewenangan yang dapat menyelesaikan hal tersebut. 


\section{Iklim Usaha Pertambangan yang Tidak Kondusif pada WIUP yang Sama Lokasinya}

Tumpang tindih Putusan Mahkamah Agung Republik Indonesia Nomor 129 K/TUN/2011 yang telah berkekuatan hukum tetap. Bupati sebagai tergugat dalam perkara a quo mencabut objek sengketa atas perintah Putusan Pengadilan. Dengan menerbitkan Surat Keputusan Bupati Konawe Utara No. 72 tahun 2012. Surat Keputusan Bupati Konawe Utara No. 72 tahun 2012 ini telah di ulas lengkap pada bab terdahulu 1(satu) dari 3 (tiga) objek sengketa yang dicabut yaitu Surat Keputusan Penjabat Bupati Konawe Utara Nomor 05 tahun 2010 tentang Pembatalan Perizinan Kuasa Pertambangan yang diterbitkan oleh Penjabat Bupati Konawe Utara dalam Wilayah Kuasa Pertambangan PT. Aneka Tambang di Kabupaten Konawe Utara.

Ratio legis dari pencabutan Surat Keputusan Penjabat Bupati Konawe Utara Nomor 05 tahun 2010 tentang Pembatalan Perizinan Kuasa Pertambangan yang diterbitkan oleh Penjabat Bupati Konawe Utara Dalam Wilayah Kuasa Pertambangan PT. Aneka Tambang di Kabupaten Konawe Utara. Maka seluruh Perizinan Kuasa Pertambangan yang diterbitkan oleh Penjabat Bupati Konawe Utara Dalam Wilayah Kuasa Pertambangan PT. Aneka Tambang di Kabupaten Konawe Utara sah dan berlaku dan mengikat di saat Perizinan Kuasa Pertambangan yang diterbitkan oleh Penjabat Bupati Konawe Utara Dalam Wilayah Kuasa Pertambangan PT. Aneka Tambang di Kabupaten Konawe Utara sah dan berlaku kembali ternyata ditahun 2010 Penjabat Bupati Konawe Utara Juga menerbitkan 7 (tujuh) Surat Keputusan Bupati Konawe Utara di atas WIUP Perizinan Kuasa Pertambangan yang diterbitkan oleh Penjabat Bupati Konawe Utara Dalam Wilayah Kuasa Pertambangan PT. Aneka Tambang di Kabupaten Konawe Utara Yakni:

1. Surat Keputusan Penjabat Bupati Konawe Utara Nomor: 12 tahun 2010 tentang Pemberian Izin Usaha Pertambangan Eksplorasi Kepada PT. Aneka Tambang (KW 99 NPP 024) seluas 6.376 ha tanggal 11 Januari 2010;

2. Surat Keputusan Penjabat Bupati Konawe Utara Nomor 13 tahun 2010 tentang Pemberian Izin Usaha Pertambangan Operasi Produksi kepada PT. Aneka Tambang (Kw NPP 001)seluas 3047 Ha, tanggal 11 Januari 2010;

3. Surat Keputusan Penjabat Bupati Konawe Utara Nomor 63 tahun 2010 tentang Pemberian Izin Usaha Pertambangan Eksplorasi Kepada PT. Aneka tambang (K (10 PEB ER 001) seluas 13410 ha tanggal 8 Februari 2010, 
4. Surat Keputusan Penjabat Bupati Konawe Utara Nomor 105 tahun 2010 tanggal 29 Maret 2010 tentang Pemberian Izin Usaha Pertambangan Operasi Produksi kepada PT. Aneka Tambang (Kw 10 MRT OP 001) seluas 13.410 ha Maret 2010;

5. Surat Keputusan Penjabat Bupati Konawe Utara dan Nomor 158 tahun 2010 tentang Pemberian Izin Usaha Pertambangan Operasi Produksi kepada PT. Aneka Tambang KW 10 APR OP 005) seluas 16.920 ha tanggal 29 April 2010.

6. Surat Keputusan Penjabat Bupati Konawe Utara Nomor 14 tahun 2010 tentang Pemberian Izin Usaha Pertambangan Eksplorasi Kepada PT Aneka Tambang (KW 99 STP057b) seluas 7.371 ha tanggal 11 Januari 2010

7. Surat Keputusan Penjabat Bupati Konawe Utara Nomor 15 tahun 2010 tentang Pemberian Izin Usaha Pertambangan Operasi Produksi (KW 99 STP 057a/Sultra) seluas 6213 ha tanggal 11 Januari 2010

Bupati Konawe Utara selain mencabut 3 Surat Keputusan Penjabat Bupati Konawe Utara yang menjadi Objek Gugatan Putusan Mahkamah Agung RI 129 K/TUN/2011 juga mencabut 7 surat Keputusan Penjabat Bupati Konawe Utara yang menyebabkan tumpang tindih WIUP di wilayah Kabupaten Konawe Utara dengan Surat Keputusan Bupati Konawe Utara Nomor 86 tahun 2012 tanggal 16 Februari 2012 tentang Pembatalan dan Pencabutan Surat Keputusan Pejabat Bupati Konawe Utara Nomor 12 tahun 2010, Nomor 13 Tahun 2010 masing-masing tanggal 11 Januari 2010, Nomor 63 tahun 2010, tanggal 8 Februari 2010, Nomor 105 tahun 2010 tanggal 29 Maret 2010 dan Nomor 158 tahun 2010 tanggal 29 April 2010.

Surat Keputusan ini Adalah satu dari 2 Surat Keputusan Bupati Konawe Utara dalam rangka melaksanakan Putusan Kasasi yang telah berkekuatan hukum tetap walaupun demikian nasib Surat keputusan ini menjadi tidak bermakna karena dijadikan Objek sengketa dalam perkara Tata Usaha Negara dalam putusan Mahkamah Agung RI Nomor. 225 K?TUN/2014 yang amar Putusan Menyatakan Menolak Permohonan Kasasi Tergugat Bupati Konawe Utara. dengan dasar Pertimbangan

Pertimbangan Bupati Konawe Utara dalam Surat Keputusan Objek sengketa Surat Keputusan Bupati Konawe Utara Nomor 86 tahun 2012 tanggal 16 Februari 2012 tentang Pembatalan dan Pencabutan Surat Keputusan Pejabat Bupati Konawe Utara Nomor 12 tahun 2010, Nomor 13 Tahun 2010 masing-masing tanggal 11 Januari 2010, Nomor 63 tahun 2010, tanggal 8 Februari 2010, Nomor 105 tahun 2010 tanggal 29 Maret 2010 dan Nomor 158 tahun 2010 tanggal 29 April 2010. Menjadi pertimbangan judex facti pada 
Pengadilan Tata Usaha Negara Kendari dikuatkan dengan Putusan Mahkamah Agung RI Nomor 225 K/TUN/2014 yaitu:

"menata kembali kawasan tambang yang tumpang tindih antara milik Penggugat dengan Perusahaan lain adalah berlebihan karena juga membatalkan Surat Keputusan Tergugat Nomor 158 tahun 2010 padahal surat keputusan Tergugat Nomor 158 tahun 2010 tersebut tidak pernah dipersoalkan dan menjadi objek sengketa dalam putusan Mahkamah Agung Nomor 129 K/TUN/2011 tanggal 9 $2011 .^{\prime \prime}$

Putusan Mahkamah Agung Nomor 129 K/TUN/2011 tanggal 9 2011telah berkekuatan hukum tetap. Bupati sebagai Tergugat diperintahkan Untuk mencabut 3 (tiga) Surat Keputusan Penjabat Bupati Konawe Utara yang menjadi objek sengketa dalam perkara a quo. Salah satu dari Surat Keputusan objek sengketa tersebut adalah Surat Keputusan Penjabat Bupati Konawe Utara No. 05 tahun 2010 tentang Pembatalan Perizinan Kuasa Pertambangan yang diterbitkan oleh Penjabat Bupati Konawe Utara Dalam Wilayah Kuasa Pertambangan PT. Aneka Tambang di Kabupaten Konawe Utara. “Putusan Mahkamah Agung Nomor 129 K/TUN/20119, justru ditahun 2014 Mahkamah Agung RI mempersalahkan Bupati Konawe Utara melakukan tindakan berlebihan karena membatalkan Surat Keputusan Penjabat Bupati Konawe Utara Nomor. 158 tahun 2010 tentang Pemberian Izin Usaha Pertambangan Operasi Produksi PT. Aneka Tambang dalam Putusannya Nomor 225 K/TUN/2014. Putusan Mahkamah Agung RI ini selain menimbulkan tumpang tindih WIUP di Kabupaten Konawe Utara juga menimbulkan ketidakpastian hukum Putusan Mahkamah Agung RI No. 129 K/TUN/2011, yang telah berkekuatan hukum tetap menyebabkan 18 (delapan belas) perizinan yang telah dinyatakan sah dan berlaku kembali dimana 5 dari 18 Perusahaan tersebut telah mendapat sertifikat clear and clean dari Kementerian Sumber Daya Mineral dan Batubara. Namun setelah keluarnya Putusan Mah Kamah Agung RI No. 225 K/TUN/2014 status clear and clean 5 Perusahaan tersebut dicabut kembali dan diberikan kepada PT. Aneka Tambang. Sementara Putusan Mahkamah Agung RI No. 225 K/TUN/2014. Dalam amar Putusannya judex facti pada Pengadilan Tata Usaha Negara Kendari dictum ke 3 memerintahkan Tergugat Bupati Konawe Utara untuk mencabut Objek sengketa perkara a quo. ${ }^{10}$ Saat Putusan Mahkamah Agung Nomor 225 K/TUN/2014 berkekuatan hukum

\footnotetext{
8 Lihat Pertimbangan Hukum Putusam Mahkamah Agung RI No. 225 K/TUN/2014, hlm. 32.

9 Lihat Amar Putusan Mahkamah Agung RI No. 129 K/TUN/2011, hlm 54

10 Lihat Amar Putusan Pengadilan Tata Usaha Negara Kendari No. 10/G/2013/PTUN.Kdi, hlm.33
} 
tetap kewenangan Bupati dibidang pertambangan telah beralih menjadi kewenangan Gubernur dan Menteri Energi dan Sumber daya Mineral, berdasarkan UU RI No. 23 tahun 2014 Tentang Pemerintahan Daerah. bila amar Putusan dikait dengan asas contrarius actus, yaitu Badan atau Pejabat Tata Usaha Negara yang menerbitkan dengan sendirinya juga berwenang untuk membatalkannya asas ini berlaku meskipun dalam Keputusan Tata Usaha Negara tersebut tidak ada klausul pengaman yang lazimnya disebutkan "Apabila dikemudian hari ternyata ada kekeliruan atau kekhilafan maka keputusan ini akan ditinjau kembali"11. Dengan demikian Putusan Mahkamah Agung RI No. 225 K/TUN bertentangan dengan asas contrarius actus. Kontroversi antara putusan dengan asas merupakan salah satu faktor tergugat sebagai Bupati tidak mengeksekusi Putusan Mahkamah Agung RI No. 225 K/TUN/2014 dan/atau Putusan Mahkamah Agung RI No. 225 K/TUN/2014 tidak memiliki kepastian hukum walaupun telah berkekuatan hukum tetap. Dua Putusan Mahkamah Agung RI walaupun telah berkekuatan hukum tetap namun tidak memberi kepastian hukum bagi pencari keadilan akibat kekhilafan judex facti dalam menafsir kan Objek sengketa di 2 (dua) putusan, dua Putusan tersebut tidak mencerminkan Marwah Peradilan sebagai pemberi keadilan bagi pencari keadilan serta Pengadilan tidak memiliki wibawa dalam Putusannya karena produk yang dihasilkannya tidak membawa manfaat bagi pencari keadilan dalam hal ini Pengusaha pemegang hak Pertambangan diwilayah yang disengketakan.

Tidak tercapainya tujuan hukum oleh 2 (dua) Putusan Mahkamah Agung tersebut berkonsekuensi terhadap beberapa perusahaan yang memegang Hak izin pertambangan merasa jenuh atas ketidakpastian hukum membuat mereka mengambil keputusan untuk meninggalkan wilayah pertambangannya, yang dimilikinya dengan mengabaikan kewajiban-kewajiban serta menelantarkan WIUP dengan tidak memperpanjang lagi Perizinan yang telah berakhir, saat ini yang mampu bertahan memenuhi seluruh kewajiban yang ada dalam IUP yang dipegangnya hanya tersisa 11 perusahaan. 11 Perusahaan inilah yang tumpang tindih dengan PT. Aneka Tambang.

Konsekuensi dari Kondisi yang demikian mengakibat kerugian yang sangat besar bagi Pencari keadilan khususnya Pengusaha pemegang hak Izin Pertambangan karena 2 (dua) Putusan tersebut tidak memberi kepastian hukum bagi mereka. Kerugian yang diderita Pengusaha Pemegang Hak Izin Usaha Pertambangan. Kerugian yang ditimbulkan

11 Philipus Hadjon dan Tatiek Djatmiati, Argumentasi Hukum, Yogyakarta: Gadjah Mada University Press, 2017, hlm. 83 
2 (dua) Putusan Mahkamah Agung RI harus ditanggung sendiri para Pemegang Hak Izin Usaha Pertambangan kerugian tersebut selain telah melakukan investasi atas WIUP yang dimiliki juga harus memenuhi kewajiban-kewajiban yang ditetapkan dalam Surat Keputusan pemberian Izin Usaha Pertambangan. Berupa: 1) Pemegang IUP wajib menyerahkan dana Jaminan reklamasi dan dana jaminan pasca tambang, 2) membayar biaya pencadangan dan Iuran Produksi serta beban gaji karyawan untuk setiap bulannya serta operasional Kantor dan biaya lain yang terkait administrasi lainnya. Bagi perusahaan yang berkemampuan modal kuat tentunya akan bertahan dan sebaliknya bagi perusahaan yang berkemampuan modal sedikit tidak akan mampu bertahan dengan beban keuangan yang berat. Yang pada gilirannya masyarakat Konawe Utara dan Daerah Kabupaten Konawe Utara serta Negara yang dirugikan.

Tidak adanya kegiatan Usaha Pertambangan di Wilayah yang disengketakan berakibat Pemutusan Hubungan kerja antara Pengusaha dengan Pekerja, tidak adanya Penghasilan Daerah dan Negara dari sektor Pertambangan.

\section{KESIMPULAN}

Berdasarkan penelitian di atas untuk menjawab isu hukum yang ada dapat disimpulkan sebagai berikut:

1. Putusan Mahkamah Agung Republik Indonesia Nomor 225 K/TUN/2014 sebagai penyebab tumpang tindih WIUP karena judex facti pada Pengadilan Tata Usaha Negara.

2. Akibat tumpang tindih putusan berkonsekuensi tidak adanya kepastian hukum, yang mengakibatkan: (1) Tidak adanya Kegiatan Penambangan oleh Pemegang Hak Izin Pertambangan baik PT. Aneka Tambang Maupun 11 Perusahaan yang tertindih WIUP-nya (2) terjadi Pemutusan hubungan Kerja besar besaran dan (3) Penghasilan Daerah dan Negara menjadi hilang dari sektor Pertambangan di WIUP yang tumpang tindih.

\section{Daftar Pustaka}

\section{Buku}

Fajar, Mukti dan Yulianto Achmad. Dualisme Penelitian Hukum Normatif dan Empiris. Yogyakarta: Pustaka Pelajar, 2010. 
Hadjon, Philipus M \& Tatiek Sri Djatmiati. Argumentasi Hukum. Yogyakarta: Gadjah Mada University Press, 2005.

Marzuki, Peter Mahmud. Penelitian Hukum. Jakarta: Kencana Prenada Media Group, 2005.

Yakoeb, Erwantoni. Kewenangan Hakim Menetapkan Tersangka. Bandung: LogozPubhlising, 2017.

\section{Perundang-undangan}

Undang-Undang Republik Indonesia Nomor 4 Tahun 2009 tentang Pertambangan Mineral dan Batubara

\section{Putusan}

Putusan Mahkamah Agung Republik Indonesia Nomor. 129 K/TUN/2011

Putusan Mahkamah Agung Republik Indonesia Nomor. 225 K/TUN/2014

Putusan Pengadilan Tata Usaha Negara Kendari No. 10/G/2013/PTUN.Kdi 